Khazanah: Jurnal Studi Islam dan Humaniora

ISSN: 0215-837X (p); 2460-7606 (e), Vol. 17 (2), 2019, pp. 283-296

DOI: $10.18592 /$ khazanah.v17i2.3214

Submit : 15/08/2019 Review : 30/08/2019 Publish : 31/12/2019

\title{
PERSPEKTIF SOSIOLOGIS TERHADAP TOLERANSI ANTAR UMAT BERAGAMA DI KOTA SINGKAWANG
}

\author{
Sri Sudono Saliro \\ Institut Agama Islam Sultan Muhammad Syafiuddin Sambas \\ srisudonosalirofh@gmail.com
}

\begin{abstract}
The purpose of this study is to analyze the religious tolerance among different communities in the city of Singkawang. It focuses on the forms of tolerance as well as the supporting and challenging factors toward tolerance among religious people in the city. This is an empirical research in which it employs descriptive qualitative methods that were used to obtain data through observation and interviews. Among the results of the field research is a finding that in Singkawang City, inter-religious relationships have been facilitated by collaborated forums namely FKUB (Forum Komunikasi Umat Beragama) and FKPELA (Forum Komunikasi Pemuda Lintas Agama). Special for FKPELA, this forum has been claimed as the only interfaith youth communication forums found in Indonesia. Among the supporting factors for the interfaith cooperations are the emotional ties and environmental conditions. In this context, the community grows and develops in an environment surrounded by people of different religions. Regarding the challenging factors, it was found that the socio-political situation and traumatic memory of conflict in the city's history could constitute as inhibiting factors.
\end{abstract}

Keywords: Tolerance; Interfaith Collaboration; Singkawang City

\begin{abstract}
Abstrak: Tujuan penelitian ini adalah untuk menganalisa toleransi beragama di antara komunitas yang berbeda di kota Singkawang. Penelitian ini berfokus pada bentuk-bentuk toleransi, serta faktor pendukung dan penghambat toleransi antar umat beragama di kota ini. Penelitian ini bersifat empiris dengan menggunakan metode kualitatif deskriptif, yang digunakan untuk memperoleh data melalui observasi dan wawancara. Di antar hasil dari penelitian lapangan tersebut adalab temuan bahwa hubungan keagaman di kota Singkawang diafasilitasi dalam sebuah wadah kolaboratif yakni FKUB (Forum Komunikasi Umat Beragama) dan FKPELA (Forum Komunikasi Pemuda Lintas Agama). Khusus FKPELA, lembaga ini dikelaim sebagai satu-satunya forum komunikasi pemuda lintas agama yang ada di Indonesia. Di antara faktor pendukung toleransi dimaksud adalah ikatan emosional dan kondisi lingkungan. Dalam hal ini, masyarakatnya tumbuh dan berkembang di lingkungan yang dikelilingi oleh orang-orangyang berbeda agama. Di sisi lain, faktor sosial politik dan beban ingatan traumatis terkait konflik dalam sejarah masyarakat di kota ini menjadi faktor penghambat.
\end{abstract}

Kata kunci: Toleransi; Kerjasama Lintas Agama; Kota Singkawang

\section{Pendahuluan}

Toleransi dalam bahasa Latin yakni "tolerare" yang memiliki arti sabar terhadap sesuatu. Jadi dapat disimpulkan bahwa toleransi merupakan ${ }^{1}$ suatu sikap atau perilaku manusia yang mengikuti aturan, dimana seseorang dapat menghargai, menghormati terhadap perilaku orang lain. Toleransi menunjukan adanya suatu kerelaan untuk

\footnotetext{
${ }^{1}$ Abu Bakar, "Konsep Toleransi dan Kebebasan Beragama," TOLERANSI: Media Komunikasi Umat Beragama Vol.7 Juli-Desember (2015): 123-31.
} 
menerima kenyataan adanya orang lain disekitar dan disamping kita. Sikap toleransi diwujudkan dalam bentuk interaksi dan kerjasama diberbagai golongan. Interaksi yang terjadi di masyarakat merupakan jaringan relasi timbal balik dalam kehidupan bermasyarakat. Pada konteks ini, interaksi sosial menjadi kebutuhan dasar manusia yang bersifat universal dan tidak dapat dibatasi oleh kelompok masyarakat tertentu sehingga perbedaan bukanlah hambatan bagi masyarakat dalam melakukan interaksi sosial.Agama yang menjadi faktor pendorong terjadinya dinamika interaksi sosial memungkinkan untuk mempengaruhi pola interaksi sosial antara umat beragama. ${ }^{2}$ Bahkan pembangunan nasional negara Indonesia memposisikan agama pada urutan teratas sebagai asas pembangunan, begitu pula dengan dasar Negara Indonesia, sila pertama dalam Pancasila adalah Ketuhanan Yang Mahaesa. ${ }^{3}$

Tjahjo Kumolo yang menjadi menteri dalam negeri pada periode 2014-20194 mengungkapkan bahwa Indonesia merupakan bangsa yang majemuk. Menurut beliau, kondisi ini menjadi tantangan untuk para kepala daerah yang harus mengimplementasikan berbagai kebijakan di masing-masing daerah dengan mengedepankan nilai-nilai Pancasila. Menyusun perencanaan dalam program kerja, menyusun Perda, mengambil sebuah kebijakan politik sekecil apapun, membuat peraturan apapun, menggerakan, mengorganisir masyarakat dimana pun berada, jika kepala daerah menjabarkan sila-sila Pancasila maka bisa terwujud dengan baik. Pernyataan ini dia ungkapkan dalam acara penghargaan oleh SETARA Institute yang menobatkan Kota Singkawang, Kalimantan Barat berada pada urutan pertama dalam penghargaan "Kota Toleran 2018" dengan skor tertinggi 6,513 dari skala penilaian 1 7.

Hal ini menunjukan betapa dominannya faktor agama dalam tata kehidupan sosial yang seakan-akan agama tidak bisa dilepaskan dari konteks hubungan antar manusia dan pembangunan. Keharmonisan dan toleransi antar pemeluk agama akan memberikan dampak bagi semua aspek kehidupan, baik itu stabilitas politik, pertumbuhan ekonomi dan perkembangan sosial dan budaya yang semakin meningkat dan berkembang pesat, begitu juga hal sebaliknya jika itu terjadi konflik, ketidakharmonisan, intoleran antar pemeluk agama.

Kota Singkawang memiliki keseluruhan keanekaragaman umat beragama yang diakui di Indonesia. Berdasarkan data dari Kementerian Agama Kota Singkawang terhitung sampai bulan Mei 2019 penduduk Kota Singkawang beragama Islam sebanyak 51,20\%, beragama Protestan sebanyak 5,35\%, beragama Katholik sebanyak 7,44\%, beragama Hindu sebanyak 0,03\%, beragama Budha sebanyak 35,49\%, dan Kong Hu Chu sebanyak 0,50\%.

Realitas diatas menunjukan bahwa kota Singkawang memiliki kemajemukan masyarakat beragama dan memiliki potensi keunggulan yang merupakan perpaduan

\footnotetext{
${ }^{2}$ Abu Bakar HM, Mualimin, dan Nurliana, "Elit Agama dan Harmonisasi Sosial Di Palangka Raya," Khazanah : Jurnal Studi Islam dan Humaniora Vol. 16 (2) (2018): 277-96.

${ }^{3}$ Rina Rehayati, "KERUKUNAN HORIZONTAL (Mengembangkan Potensi Positif dalam Beragama)," Toleransi 1, no. 1 (2009): 55-64.

${ }^{4}$ Ghita Intan, "SETARA Institute: Singkawang, Kota Paling Toleran Se-Indonesia," 2018. 
dari berbagai macam latar belakang budaya yang saling melengkapi dan hidup berdampingan secara harmonis dan toleransi antar umat beragama guna mendukung pembangunan di Kota Singkawang. Hubungan harmonis antar umat beragama berpengaruh pada umat masing-masing agama

Dari ungkapan Hendardi (Ketua SETARA Institute) ${ }^{5}$, Kota Singkawang merupakan kota dengan penilaian indeks kota toleran tertinggi pada tahun 2018 berdasarkan penilaian yang menunjukkan bahwa kota ini paling sukses dalam menerapkan toleransi melalui Rencana Pembangunan Jangka Menengah Daerah (RPJMD) dan produk hukum lainnya yang dibuat Kota Singkawang.

Sesuai dengan penjelasan diatas yang mengenai toleransi umat beragama sebagai landasan dalam melaksanakan sikap dan perilaku umat beragama, makalah ini ditulis untuk mengangkat permasalahan toleransi antar umat beragama di kota Singkawang dalam perspektif sosial. Dengan topik ini, fokus permasalahan yang akan dikaji adalah: 1) apa saja bentuk kerjasama antar umat beragama; dan 2) apa faktor pendukung dan penghambat toleransi umat beragama di Kota Singkawang.

\section{Metode}

Penelitian ini menggunakan metode kualitatif yang menekankan pada kedalaman nilai. ${ }^{6}$ Metode ini digunakan untuk mencoba menjawab secara keseluruhan mengenai toleransi antar umat beragama di Kota Singkawang dalam perspektif sosiologis. Selain itu, penelitian ini menggunakan pendekatan deskriptif kualitatif yang menguraikan permasalahan secara deskriptif dengan melihat konteks permasalahan dan tindakan individu dalam suatu rangkaian sosial di masyarakat. Pendekatan deskriptif ini dipakai karena untuk mengungkap realita sosial agar tergambarkan bentuk kerjasama antar umat beragama dan penerapannya terhadap sikap dan perilaku masyarakat beragama di Kota Singkawang. Namun demikian penelitian ini tetap memanfaatkan data statistik umat beragama yang dikumpulkan dari data lapangan. Dalam penelitian ini yang menjadi data primer yaitu masyarakat Kota Singkawang, tokoh agama, dan pemerintah. Adapun dari keseluruhan populasi diatas, peneliti menetapkan sampel yang menjadi sumber data menggunakan purposive sampling yaitu berdasarkan tujuan yang ingin dicapai dalam penelitian ini. ${ }^{7}$ Adapun sebagai data sekunder diantaranya: buku, surat kabar, jurnal dan peraturan perundang-undangan yang relevan dengan fokus kajian ini. Teknik pengumpulan data menggunakan pengamatan, wawancara berpedoman (guided interview) dan wawancara mendalam (indepth interview) dan teknik dokumentasi. Teknik pengumpulan data menggunakan pengamatan maksudnya adalah teknik pengumpulan data dengan cara peneliti melakukan pengamatan secara langsung di lapangan dan mencatat secara sistematis gejala yang diselidiki. ${ }^{8}$ Sedangkan wawancara berpedoman dimaksudkan agar

2018.

${ }^{5}$ Ninis Chairunnisa, "Indeks Kota Toleran: Singkawang Tertinggi, Tanjung Balai Terendah,"

${ }^{6}$ Agus Salim, Teori dan Paradigma Penelitian Sosial (Yogyakarta: Tiara Wacana Yogya, 2001), 11.

${ }^{7} \mathrm{M}$ Atho Mudzhar, Pendekatan Studi Islam dalam Teori dan Praktek (Yogyakarta: Pustaka Pelajar, 1998), 70.

${ }^{8}$ Arikunto, Suhardjono, dan Supardi, Penelitian Tindakan Kelas (Jakarta: Bumi Aksara, 2012), 88.

Khazanah, Vol. 17 (2), 2019 
mendapatkan data dan informasi terarah sehingga memungkinkan untuk melakukan pengembangan pertanyaan berdasarkan jawaban informan. Selain itu wawancara mendalam dilakukan kepada pihak terkait masyarakat kota Singkawang dalam melaksanakan toleransi umat beragama. ${ }^{9}$ Teknik analisis data menggunakan analisis deskriptif, yang menurut Sutrisno Hadi analisis deskriptif ini bertujuan agar dapat menggambarkan keadaan dan status fenomena. ${ }^{10}$ Setelah menemukan data kualitatif dari lapangan yang tentunya tetap memperhatikan prinsip validitas dan objektifitas data, kemudian dianalisis dengan instrumen deduktif dan induktif baik itu data yang bersifat primer dan sekunder sehingga dapat mengetahui secara mendalam terkait penelitian ini.

\section{Pembahasan}

\section{Singkawang Kota Toleran 2018}

Toleransi merupakan salah satu variabel kunci dalam membina dan mewujudkan kerukunan dan inklusi sosial, serta membangun Negara Pancasila yang bersendikan kemerdekaan beragama sebagaimana termuat didalam sila pertama Pancasila dan dijamin oleh Undang-Undang Dasar Negara Republik Indonesia tahun 1945, terutama Pasal 29 Ayat (2) yaitu "Negara menjamin kemerdekaan tiap-tiap penduduk untuk memeluk agamanya masing-masing dan untuk beribadat menurut agamanya dan kepercayaannya itu." Selain itu Pemerintah daerah khususnya kota yang heterogenitas sosio-kulturalnya lebih tinggi daripada kabupaten, merupakan organ masyarakat dituntut untuk memainkan peran positif sebagai representasi Negara dalam sisi yang lebih spesifik dan partikular.

Dalam konteks itu, dan dalam rangka memperingati Hari Toleransi Internasional yang diperingati setiap tanggal 16 Nopember setiap tahun, SETARA Institute melakukan kajian dan indexing terhadap 94 kota di Indonesia dalam hal isu promosi dan praktik toleransi. SETARA Institute mengungkapkan tujuan dari pengindeksan ini antara lain untuk mempromosikan kota-kota yang dianggap berhasil membangun dan mengembangkan toleransi di wilayahnya masing-masing sehingga menjadi pemicu bagi kota-kota lain untuk turut bergegas mengikuti, membangun dan mengembangkan toleransi di wilayahnya. ${ }^{11}$

Laporan tentang Indeks Kota Toleran tahun 2018 adalah laporan yang disusun dengan mengutamakan praktik-praktik toleransi terbaik kota-kota di Indonesia, dengan memeriksa seberapa besar kebebasan beragama/berkeyakinan dijamin dan dilindungi melalui regulasi dan tindakan di satu sisi serta menyandingkannya dengan realitas perilaku sosial kemasyarakatan dalam tata kelola keberagaman kota, khususnya dalam isu agama/keyakinan. Pengukuran yang dilakukan SETARA Institute menggunakan

${ }^{9} \mathrm{H}$ Noeng Muhadjir, Metode Penelitian Kualitatif: Pendekatan Positifistik, Rasionalistik, Phenomenologik, dan Realisme Metaphistik, telaah studi teks dan penelitian agama (Yogyakarta: Rake Sarasin, 1996), 39.

${ }^{10}$ Sutrisno Hadi, Metodologi Research Jilid 2 (Yogyakarta: Andi Offset, 2004), 36.

${ }^{11}$ Ghita Intan, "SETARA Institute: Singkawang, Kota Paling Toleran Se-Indonesia," VOA Indonesia, 2018, https://www.voaindonesia.com/a/setara-institute-singkawang-kota-paling-toleranse-indonesia/4690956.html. 
paradigma negative rights, sesuai dengan karakter kebebasan beragama/ berkeyakinan yang merupakan rumpun kebebasan sipil politik, yang diukur secara negatif. Selain pendekatan negative rights, Indeks Kota Toleran juga memeriksa tindakan positif pemerintah kota dalam mempromosikan toleransi, baik yang tertuang dalam kebijakan, pernyataan resmi, respons atas peristiwa, maupun membangun budaya toleransi di masyarakat. ${ }^{12}$

Secara operasional SETARA Institute menurunkan konsep toleransi pada beberapa variabel sistemik di kota yang mempengaruhi perilaku sosial antar identitas dan entitas warga kota, yaitu meliputi kebijakan-kebijakan pemerintah kota, tindakantindakan aparatur pemerintah kota, perilaku antar entitas di kota - warga dengan warga, pemerintah dengan warga, dan relasi-relasi dalam heterogenitas demografis warga kota.

Dengan demikian yang dimaksud dengan kota toleran dalam studi SETARA Institute adalah kota yang memiliki beberapa atribut berikut: 1) Pemerintah kota tersebut memiliki regulasi yang kondusif bagi praktik dan promosi toleransi, baik dalam bentuk perencanaan maupun pelaksanaan; 2) Pernyataan dan tindakan aparatur pemerintah kota tersebut kondusif bagi praktik dan promosi toleransi; 3) Di kota tersebut, tingkat peristiwa dan tindakan pelanggaran kebebasan beragama/berkeyakinan rendah atau tidak ada sama sekali; 4) Kota tersebut menunjukan upaya yang cukup dalam tata kelola keberagaman identitas keagamaan warganya. ${ }^{13}$

Pengukuran toleransi yang dilakukan oleh SETARA Institute dalam mengukur Indeks Kota Toleran (IKT) tahun 2018 menggunakan pendapat Brian J. Grim dan Roger Finke ${ }^{14}$ menyusun 3 indikator utama untuk mengukur tingkat kebebasan beragama/derajat toleransi sebuah negara. Pertama, favoritisme atau pengistimewaan pemerintah terhadap kelompok-kelompok agama tertentu. Kedua, peraturan pemerintah yang membatasi kebebasan beragama. Ketiga, regulasi sosial yang membatasi kebebasan beragama. ${ }^{15}$ Ketiganya kemudian ditambah lagi dengan satu lagi variabel lain, yaitu komposisi penduduk berdasarkan agama.

Komposisi penduduk menjadi salah satu parameter dalam mengukur indikator toleransi dalam tata kelola kota karena objek studi ini adalah 94 kota dari total 98 kota di seluruh Indonesia. Penggabungan kota-kota administrasi di DKI Jakarta menjadi Kota DKI Jakarta karena kota-kota tersebut tidak memiliki kewenangan untuk mengeluarkan peraturan perundang-undangan, sehingga tidak valid untuk dinilai secara terpisah. Pemilihan kota sebagai objek penelitian didasarkan pada pertimbangan bahwa komposisi penduduk di perkotaan seharusnya lebih heterogen jika dibandingkan dengan kabupaten. Kondisi heterogenitas dan kosmopolitanisme ini seharusnya

${ }^{12}$ Titin Nuryani dan Ahmad Taufiq, "Peran Forum Kerukunan Umat Beragama dalam Memelihara Toleransi Beragama Kota Salatiga Tahun 2018," Journal of Politic and Government Studies 8, no. 03 (2019): 381-390.

13SETARA Institute, “Ringkasan Eksekutif Indeks Kota Toleran Tahun 2018,” 2018, 3.

14"Measuring international socio-religious values and conflict by coding US State Department reports," JMS Proceedings, A APOR-Section on Survey Research Methods [CD-ROM]. Alexandria, VA: American Statistical Association, 2006, 4120-27.

${ }^{15}$ SETARA Institute, "Ringkasan Eksekutif Indeks Kota Toleran Tahun 2018," 2.

Khazanah, Vol. 17 (2), 2019 
menunjukkan tingkat toleransi yang tinggi. Pemilihan 94 kota ini juga didasarkan pada kepentingan praktis memudahkan kegiatan penelitian, dibandingkan dengan meneliti seluruh kabupaten/kota di Indonesia yang berjumlah $514 .{ }^{16}$

Berdasarkan pada definisi operasional diatas ditambah dengan kerangka indexing, para ahli menetapkan 4 (empat) variabel sebagai alat ukur dengan mengutip kerangka pengukuran yang dikemukakan oleh Grim dan Finke, ${ }^{17}$ yaitu: a) Regulasi Pemerintah Kota dengan indikator (1) Rencana pembangunan dalam bentuk Rencana Pembangunan Jangka Menengah Daerah (RPJMD) dan produk hukum pendukung lainnya dan (2) Kebijakan diskriminatif; b) Tindakan Pemerintah dengan indikator: (1) Pernyataan pejabat kunci tentang peristiwa intoleransi dan (2) Tindakan nyata terkait peristiwa]; c) Regulasi Sosial dengan indikator: (1) Peristiwa intoleransi dan (2) Dinamika masyarakat sipil terkait peristiwa intoleransi); d) Demografi Agama dengan indikator: (1) Heteregonitas keagamaan penduduk, dan (2) Inklusi sosial keagamaan. Dengan demikian, dibandingkan dengan indikator pada tahun sebelumnya, terdapat penambahan pada variabel Regulasi Sosial, yaitu berupa indikator Dinamika Masyarakat Sipil, dan pada variabel Demografi Agama, yaitu berupa Inklusi Sosial Keagamaan.

Berdasarkan hasil observasi yang didapat di Kantor Walikota Singkawang pada tanggal 22 Juli 2019 pukul $10.00 \mathrm{Wib}$, menjelaskan bahwa yang menjadi sumber data penelitian untuk menentukan indikator tolak ukur tingkat toleransi berdasarkan sumber yang diperoleh dari dokumen resmi pemerintah kota, data Biro Pusat Statistik (BPS), data Komnas Perempuan, data SETARA Institute, dan referensi media terpilih. Data tersebut dalam bentuk:

1. RPJMD (Rencana Pembangunan Jangka Menengah Daerah) kota. Data ini bisa diakses siapa saja, sehingga memudahkan bagi pihak-pihak yang ingin melakukan pemeriksaan terhadap rencana daerah (dalam penelitian ini adalah RPJMD Kota Singkawang). RPJMD dikeluarkan oleh masing-masing daerah untuk rentang waktu lima tahun sekali, sehingga terjadi perbedaan rentang waktu mulai dan selesainya sebuah RPJMD.

2. Dalam implementasinya dokumen RPJMD kota Singkawang tahun 2018-2022 yang telah ditetapkan dalam peraturan daerah nomor 3 tahun 2018 tentang RPJMD kota Singkawang menjadi landasan bagi seluruh pemangku kepentingan antara lain, seluruh perangkat daerah, masyarakat, para tokoh agama, tokoh masyarakat, para pakar dan akademisi serta kalangan dunia dalam perumusan kebijakan perencanaan, pelaksanaan, dan pengendalian serta pemantauan dalam upaya terwujudnya pelaksanaan pembangunan yang transparan, adil, demokratis, efektif dan akuntabel. Visi misi kota Singkawang 2018-2022 juga tertuang didalam dokumen RPJMD, yang merupakan bentuk dukungan terhadap toleransi antar umat beragama yaitu mewujudkan dan memelihara harmonisasi dalam keberagaman agama, etnis dan budaya.

3. Peraturan Daerah/Kebijakan Kota Lainnya. Sumber data ini diperoleh dari Komnas Perempuan yang telah menghimpun peraturan-peraturan daerah yang

\footnotetext{
${ }^{16}$ SETARA Institute, 2-3.

${ }^{17}$ SETARA Institute, 3.
} 
bermuatan diskriminatif antara tahun 2009 hingga tahun 2017 dan data kebijakan diskriminatif yang dicatat SETARA sejak tahun 2017 hingga 2018. Selama peraturan perundang-undangan yang bersangkutan masih berlaku atau belum dicabut, maka peraturan perundang-undangan tersebut masih valid digunakan sebagai alat ukur.

4. Peristiwa yang menggambarkan terjadinya intoleransi. Data ini diambil dari data peristiwa dan tindakan pelanggaran kebebasan beragama/ berkeyakinan yang dikumpulkan melalui riset pemantauan SETARA Institute, yang sudah sejak 2007 didokumentasikan dan dilaporkan dilaporkan kepada publik setiap tahun. Untuk pengukuran tahun berjalan (2018) dilakukan atas peristiwa dan tindakan dalam rentang waktu antara November 2017 hingga Oktober 2018. Di kota Singkawang tercatat tidak ada peristiwa yang terjadi berkaitan dengan intoleran.

5. Tindakan Nyata Pemerintah Kota. Tindakan pemerintah diukur berdasarkan tindakan atau aksi yang diambil oleh pemerintah kota dalam menyikapi sebuah kasus atau peristiwa. Untuk mengumpulkan informasi tindakan pemerintah studi indexing ini menggunakan data sekunder melalui penelusuran informasi di media massa dalam rentang waktu pemberitaan adalah sejak November 2017 hingga Oktober 2018 dan data pemantauan SETARA Institute tentang kebebasan beragama/berkeyakinan.

6. Pernyataan Pemerintah, yang dimaksud adalah respons pemerintah kota dalam menyikapi peristiwa atau kejadian yang mengandung intoleransi berbasis agama/keyakinan. Data untuk variabel ini juga dirujuk dari pemberitaan media menggunakan beberapa beberapa kata kunci generik, yaitu toleransi, kebebasan beragama, kesetaraan jender, kerukunan umat beragama, kebinekaan, dan Pancasila dikaitkan dengan kata kunci masing-masing kota. Rentang waktu pemberitaan adalah sejak November 2017 hingga Oktober 2018. Selain itu, data juga dihimpun dari hasil pemantauan yang dilakukan oleh para peneliti SETARA Institute atas peristiwa-peristiwa pelanggaran kebebasan beragama/berkeyakinan.

7. Dinamika masyarakat sipil. Data mengenai partisipasi dan dinamika masyarakat sipil dalam praktik dan pemajuan toleransi dikumpulkan melalui penelusuran data sekunder yang dilakukan oleh para peneliti SETARA Institute yang dikuatkan dengan data self-assessment yang dihimpun oleh SETARA Institute melalui kuesioner.

8. Demografi Penduduk Berdasarkan Agama. Data ini tersedia di website BPS (Badan Pusat Statistik) dan bisa diakses oleh siapa saja yang membutuhkan. Data yang tersedia di BPS adalah komposisi penduduk kabupaten/kota, salah satunya berdasarkan agama/ keyakinan yang masih dalam bentuk angka. Dalam penelitian ini, data angka kemudian dikonversi ke dalam persentase. Berdasarkan data dari Kementrian Agama Kota Singkawang terhitung sampai bulan Mei 2019 penduduk Kota Singkawang beragama Islam sebanyak 51,20\%, beragama Protestan sebanyak 5,35\%, beragama Katholik sebanyak 7,44\%, beragama Hindu sebanyak 0,03\%, beragama Budha sebanyak 35,49\%, dan Konghucu sebanyak 0,50\%.

9. Inklusi sosial keagamaan. Data ini dalam bentuk data sekunder melalui penelusuran pemberitaan media massa yang terpercaya mengenai kerukunan antar umat 
beragama dan harmoni sosial keagamaan di masing-masing kota. Rentang waktu pemberitaan adalah sejak November 2017 hingga Oktober 2018.

Scoring dalam studi SETARA Institute menggunakan skala dengan rentang nilai 1-7, yang menggambarkan rentang gradatif dari kualitas buruk ke baik. Artinya, 1 merupakan scoring untuk situasi paling buruk pada masing-masing indikator untuk mewujudkan kota toleran, sedangkan 7 adalah scoring untuk situasi paling baik pada masing-masing indikator untuk mewujudkan kota toleran di kota-kota dimaksud.

SETARA Institute menetapkan 10 (sepuluh) kota dengan skor toleran tertinggi adalah sebagai berikut:

1. Kota Singkawang Skor 6.513

2. Kota Salatiga Skor 6.477

3. Kota Pematang Siantar Skor 6.280

4. Kota Manado Skor 6.030

5. Kota Ambon Skor 5.960

6. Kota Bekasi Skor 5.890

7. Kota Kupang Skor 5.857

8. Kota Tomohon Skor 5.833

9. Kota Binjai Skor 5.830

10. Kota Surabaya Skor $5.823 .^{18}$

\section{Bentuk Kerjasama Antar Umat Beragama di Kota Singkawang}

Sesuatu yang tidak dapat dipisahkan dalam kehidupan masyarakat adalah adanya kerjasama dan interaksi sosial. Menurut Soejono Soekanto di dalam bukunya tentang pengantar sosiologi, interaksi sosial adalah faktor utama dalam kehidupan sosial. ${ }^{19}$ Dengan adanya kerjasama dan interaksi sosial sesama manusia atau pemeluk agama akan lebih mempererat hubungan bersama, hal sebaliknya apabila tidak ada komunikasi atau interaksi antar satu sama lain maka tidak ada kehidupan bersama. Mencapai sebuah kerukunan salah satunya adalah toleransi, untuk mewujudkan toleransi diperlukan kerjasama. Terbentuknya suatu kesepahaman untuk bekerjasama tidak lah mudah, bahkan dalam satu kelompok terjadi perbedaan pendapat apalagi kerjasama disini dimaksudkan adalah kerjasama antar umat beragama yang notabene di kota Singkawang memiliki 6 (enam) agama dan kepercayaan antara lain: Islam, Protestan, Katholik, Budha, Hindu, Konghucu. Kerjasama untuk mewujudkan suatu kerukunan umat beragama melalui unsur toleransi diperlukan suatu model toleransi terbaik, menurut Atho' sebagaimana dikutip oleh Rina bahwa salah satu model terbaik menyelesaikan benturan agama adalah melalui dialog pengembangan wawasan multikultural antar pemuka agama. Dengan dialog diharapkan tercapai pemahaman yang lebih baik disamping mewaspadai berbagai faktor yang terkait hubungan antar umat beragama, baik yang mendorong konflik maupun memiliki potensi integrasi.

18SETARA Institute, 5.

${ }^{19}$ Soerjono Soekanto, Sosiologi: Suatu Pengantar (Jakarta: Raja Grafindo Persada, 2007), 68. 
Melalui sarana dialog akan mengidentifikasi kearifan lokal guna merajut kerukunan beragama. ${ }^{20}$

Kondisi keagamaan dan budaya di kota Singkawang yang majemuk perlu dikembangkan melalui sarana komunikasi yang efektif di daerah guna meredam potensi konflik. Kemajemukan yanga ada tersebut menciptakan polarisasi dalam pengelompokan atau kelas sosial masyarakat. Keberagaman jenis suku, ras dan agama di Kota Singkawang maka tidak terhindarkan munculnya permasalahan sosial terutama kaitannya dalam kehidupan beragama. Kondisi kota yang sedang berkembang tidak terhindarkan banyaknya potensi konflik yang terjadi. Tidak jarang terjadi perselisihan di masyarakat yang mengetengahkan isu agama seperti pendirian rumah ibadah, unsur politik. Permasalahan itu muncul antara lain adanya pendirian rumah ibadah yang tidak mempunyai izin, penggunaan fasilitas umum sebagai tempat ibadah dan munculnya protes warga terhadap keberadaan suatu rumah ibadah, serta unsur politik pemilihan kepala daerah.

Salah satu kebijakan yang ditetapkan pemerintah pada tahun 2006 terkait masalah kehidupan beragama adalah ditetapkannya Peraturan Bersama Menteri Agama dan Menteri Dalam Negeri Nomor 8 dan 9 Tahun 2006 tentang pedoman pelaksanaan tugas kepala daerah/wakil kepala daerah dalam pemeliharaan kerukunan umat beragama, pemberdayaan forum kerukunan umat beragama dan pendirian rumah ibadat, berlandaskan peraturan tersebut maka perlu kebijakan pemerintah daerah dalam mewujudkan toleransi kehidupan beragama di kota Singkawang dengan mengoptimalkan peran Forum Kerukunan Umat Beragama (FKUB) kota Singkawang.

Berdasarkan hasil observasi yang didapat di kantor Kemenag kota Singkawang tentang peran pemerintah terhadap praktik dan promosi toleransi, baik itu dalam bentuk perencanaan maupun pelaksanaannya, sudah termuat di dalam visi kota Singkawang yaitu harmonis dalam keberagaman agama, etnis dan budaya dan misi kota Singkawang yakni mewujudkan dan memelihara harmonisasi dalam keberagaman agama, etnis dan budaya. Tidak hanya itu, pernyataan dan tindakan pemerintah kota Singkawang bagi praktik dan promosi toleransi ditunjukan dengan adanya FKUB kota Singkawang yang dibentuk oleh masyarakat dan di tetapkan melalui surat keputusan Walikota Singkawang dalam rangka membangun, memelihara dan memberdayakan umat beragama untuk kerukunan dan kesejahteraan. Di samping itu juga ada Forum Komunikasi Pemuda Lintas Agama (FKPELA) yang menaungi pemuda-pemuda dari berbagai umat beragama di Kota Singkawang yang dibentuk oleh pemuda Kota Singkawang dan ditetapkan melalui surat keputusan Walikota Singkawang.

Dari pernyataan diatas dan hasil observasi menunjukan bahwa pemerintah kota Singkawang menggali dan menjabarkan nilai-nilai yang tertuang di dalam Pancasila melalui asas otonomi daerah desentralisasi yang merupakan semangat pemerintah daerah kota Singkawang untuk mewujudkan dan melaksanakan visi dan misinya. Artinya ketika bicara tentang toleransi, pemerintah daerah sudah menaungi hal tersebut.

\footnotetext{
${ }^{20}$ Rehayati, "Kerukunan Horizontal (Mengembangkan Potensi Positif dalam Beragama)."
}

Khazanah, Vol. 17 (2), 2019 
Adapun peran FKUB Kota Singkawang antara lain: 1) melakukan dialog dengan pemuka agama dan tokoh masyarakat; 2) menampung aspirasi ormas keagamaan dan aspirasi masyarakat; 3) menyalurkan aspirasi ormas keagamaan dan masyarakat dalam bentuk rekomendasi sebagai bahan kebijakan walikota; 4) melakukan sosialisasi peraturan perundang-undangan dan kebijakan dibidang keagamaan yang berkaitan dengan kerukunan umat beragama dan pemberdayaan masyarakat; dan 5) memberikan rekomendasi tertulis atas permohonan pendirian rumah ibadat.

Berdasarkan hasil wawancara dengan ketua FKUB Kota Singkawang, bapak Baharuddin mengatakan bahwa FKUB Kota Singkawang yang sudah berdiri pada tahun 2007 itu diadakan untuk menanggapi permasalahan isu agama yang terangkat kepermukaan pada Pilkada Walikota/Wakil Walikota Singkawang. Kegiatan FKUB di antaranya adalah dialog antar tokoh agama yang dihadiri oleh setiap umat beragama pada masing-masng agama yang ada di kota Singkawang. Dialog tersebut bertemakan Pilkada damai, semua tokoh agama baik itu agama Islam, Protestan, Katholik, Hindu, Budha, Konghucu sepakat dalam pelaksanaan Pilkada secara damai. Hasil kesepakatan tokoh masing-masing agama tersebut dituangkan dalam pakta integritas.

Selanjutnya, bapak Baharuddin juga menerangkan bahwa upaya untuk memperkuat toleransi antar umat beragama di kota Singkawang adalah dengan membangun dialog antar umat beragama yang merupakan suatu hal yang prinsipil dan utama yang harus diperhatikan ketika berbicara tentang dialog antar agama adalah bahwa dialog hendaknya memiliki batasan-batasan dan ruang lingkup didalam dialog antara lain: Pertama, dialog teologis yang bertujuan untuk membangun kesadaran bahwa diluar keyakinan dan keimanan diri ternyata ada banyak sekali keyakinan dan iman dari tradisi dan budaya agama lain. Dialog teologis dapat memposisikan iman seseorang ditengah-tengah iman orang lain. ${ }^{21}$ Batasan dialog teologis yaitu dialog antar kitab suci misalnya harus berbuat baik dengan sesama manusia, harus hidup saling bertoleransi, dan damai, yang mana hal tersebut secara umum terdapat di dalam semua kitab suci. Kedua, dialog non-teologis, menurut Swidler sebagaimana dikutip oleh Zakiyudin, dialog ini merupakan wilayah praktis dimana kita berkolaborasi untuk menolong sesama manusia. ${ }^{22}$ Dialog non teologis ini mencakup segala bentuk baik kehidupan sebagai interaksi antar umat beragama dalam suatu komunitas, kerjasama dan hubungan sosial antar agama, hal ini sudah dilaksanakan di dalam FKUB itu sendiri.

Peran pemuda mengambil bagian penting dalam toleransi umat beragama, melalui FKPELA kota Singkawang yang mulai berdiri sejak tahun 2017, peran pemuda yang harus siap mengahadapi ancaman dan siap pula manjawab tantangan yang ada. Salah satu nilai yang harus ada pada pemuda adalah jiwa kepemimpinan. Yang mana kepemimpinan sebagai salah satu soft skill, menjadi salah satu syarat eksistensi dan resistensi pemuda dalam menghadapi tantangan global. Hal ini menjadi sebuah agenda penting bagi kita bersama untuk kembali memupuk jiwa kepemimpinan pemuda mengingat arus globalisasi yang ditandai dengan keterbukaan informasi dan berbagai

${ }^{21}$ Mun'im A Sirry, Fiqih Lintas Agama (Jakarta: Yayasan Wakaf Para Madina, 2003), 224.

22Zakiyuddin Bhaidawy, Dialog Global dan Masa Depan Agama (Surakarta: Muhammadiyah University Press, 2001), 29. 
kesempatan kadang tidak disertai dengan kesiapan penyaringan informasi yang diterima oleh masyarakat, baik itu ideologi, berita hoax yang bisa merusak moral dan persatuan bangsa.

FKPELA kota Singkawang yang beranggotakan masing-masing umat beragama tanpa terkecuali memiliki tanggung jawab menjaga kerukunan dengan cara menjaring pemuda-pemuda umat beragama. Penjaringan dan upaya merangkul pemuda umat beragama di mulai dari tiap-tiap anggotanya yang membina kelompok agamanya masing-masing, sebagai contoh, anggota FKPELA yang beragama Islam akan merangkul kelompok-kelompok pemuda yang beragama Islam melalui majelis taklim, pengajian dll, begitu juga dengan agama lain.

Berdasarkan hasil wawancara pada tanggal 12 Agustus 2019 pukul 14.00 WIB dengan ketua FKPELA kota Singkawang, Bapak Rabuansyah mengatakan bahwa dalam menjaga toleransi umat beragama selalu memberikan respon terkait isu terkini baik itu dalam bentuk media sosial maupun media cetak, selain itu juga FKPELA pada berbagai kegiatan ceremonial keagamaan selalu hadir pada acara tersebut, misalnya kegiatan Cap Go Meh, anggota FKPELA ikut terlibat dalam kepanitiaan sebagai bentuk dukungan kelancaran acara tersebut, begitu juga dengan acara keagamaan lainnya. Dalam rangka peningkatan kualitas dan kapasitas anggota FKPELA, diadakanlah dialog, pelatihan dan workshop terkait isu toleransi yang diadakan oleh pemerintah daerah maupun Kanwil Kemenag Provinsi.

Dari observasi diatas setidaknya ada lima unsur kualitas kerukunan umat beragama di Kota Singkawang terpenuhi, sebagaimana yang dikatakan oleh Ridwan Lubis $^{23}$ antara lain: Pertama, nilai religiusitas, kualitas kerukunan hidup umat beragama harus merepresentasikan sikap religius umatnya. Toleransi terbangun hendaknya merupakan bentuk dan suasana hubungan yang tulus yang didasarkan pada motif-motif suci dalam rangka pengabdian kepada Tuhan. Oleh karena itu, toleransi benar-benar dilandaskan pada nilai kesucian, kebenaran, kebaikan dalam rangka mencapai keselamatan dan kesejahteraan umat. Kedua, kualitas toleransi hidup umat beragama harus mencerminkan pola interaksi antar umat beragama yang harmonis, yakni hubungan serasi, senada dan seirama, sikap tenggang rasa, dan saling menghormati, saling mengasihi saling peduli berdasarkan nilai persahabatan. Menurut pengamatan penulis, di café-café, warung kopi maupun di tempat komunitas, pemuda kota Singkawang bersikap baik terhadap sesama umat beragama, berbaur tanpa memandang sisi agama apa yang dianut oleh rekannya. Hal ini menunjukan bahwa ikatan emosional pemuda kota Singkawang sangat mempengaruhi sikap dan perilaku toleransi antar umat beragama. Ikatan emosional artinya meliputi ikatan tali persahabatan, ikatan persaudaraan, kekeluargaan dan rasa sepenanggungan baik itu sisi ekonomi maupun sosial, faktor tambahan lainnya adalah karena faktor lingkungan, yang notabene pemeluk agama baik itu, Islam, Protestan, Katholik, Budha, Hindu, Konghucu ditiaptiap kecamatan selalu ada. Ketiga, kualitas toleransi umat beragama harus diarahkn pada pada pengembangan nilai-nilai dinamik yang direpresentasikan dengan suasana yang interaktif, bergerak kedepan, bersemangat dalam mengembangkan nilai kepedulian,

${ }^{23}$ Ridwan Lubis, Cetak Biru Peran Agama (Jakarta: Puslitbang, 2005), 12-13.

Khazanah, Vol. 17 (2), 2019 
keaktifan dan kebajikan bersama. Keempat, kualitas kerukunan hidup umat beragama harus diorientasikan pada pengembangan suasana kreatif, sebagai contoh, terbentuknya FKPELA kota Singkawang dalam konteks kreatifitas interaktif, yang mana segala aspirasi pemuda lintas agama akan mengembangkan gagasan, upaya untuk meningkatkan nilai-nilai sosial dalam bertoleransi antar umat beragama. Kelima, kualitas toleransi ditekankan pada pembentukan suasana nilai produktivitas umat, seperti mengembangkan amal kebajikan, bakti sosial, kerjasama sosial ekonomi yang mensejahterakan umat.

\section{Faktor Pendukung dan Penghambat Toleransi Umat Beragama}

Adapun yang menjadi faktor pendorong toleransi umat beragama di kota Singkawang berdasarkan hasil observasi yang dilakukan kepada tokoh agama, pemerintah daerah, Kemenag Kota Singkawang dapat disimpulkan sebagai berikut adalah:

1. Faktor tokoh. Artinya faktor ini memiliki peran dan pengaruh penting dalam kehidupan bersosial di masyarakat seperti Ulama, Kyai, Ustadz, Bhiksu, Pedanda, Romo, Paus, Pendeta, Jiao Sheng (penebar agama Konghucu), tokoh masyarakat adat dan tokoh etnis. Peran tokoh ini dihadirkan pada acara seminar kebangsaan ataupun acara deklarasi perdamaian. Misalnya pada saat Pilkada Kota Singkawang dan Pilkada Gubernur Kalimantan Barat, dalam acara tersebut para tokoh agama dan tokoh masyarakat adat, maupun tokoh etnis dihadirkan untuk menjadi pembicara dalam rangka mendeklarasikan Pemilu Damai.

2. Faktor pemerintah. Adapun peran pemerintah daerah Kota Singkawang selalu memprioritaskan keharmonisan umat beragama, hal ini tercermin pada Perda Kota Singkawang No. 3 Tahun 2018 tentang RPJMD, termuat didalam Visi dan Misi Walikota dan Wakil walikota Singkawang, dan ditetapkannya Surat Keputusan walikota tentang FKUB dan FKPELA.

3. Faktor lingkungan. Secara demografi, penyebaran agama di kota Singkawang terbilang merata di berbagai kecamatan. (1) Kecamatan Singkawang Tengah beragama Islam sebanyak 76,90\%, beragama Protestan sebanyak 3,48\%, beragama Katholik sebanyak 1,70\%, beragama Hindu sebanyak 0,02\%, Beragama Budha sebanyak 14, 10, dan beragama Konghucu sebanyak 0,8\%. (2) Kecamatan Singkawang Barat beragama Islam sebanyak 30,64\%, beragama Protestan sebanyak 9,24\%, beragama Katholik sebanyak 3,57\%, beragama Hindu sebanyak 0,92\%, beragama Budha sebanyak 55,03\%, dan Konghucu sebanyak 0,60\%. (3) Kecamatan Singkawang Timur, beragama Islam sebanyak 19,26\%, beragama Protestan sebanyak $11,58 \%$, beragama Katholik sebanyak 45,56\%, beragama Hindu sebanyak 0,09\%, beragama Budha sebanyak 23,34\%, dan beragama Konghucu sebanyak 0,17\%. (4) Kecamatan Singkawang Utara beragama Islam sebanyak 74,68\%, beragama Protestan sebanyak 3,79\%, beragama Katholik sebanyak 4,80\%, beragama Budha sebanyak 16,42\%, beragama Hindu sebanyak 0,01\%, beragama Konghucu sebanyak 0,31\%. (5) Kecamatan Singkawang Selatan beragama Islam sebanyak 42,89\%, beragama Protestan sebanyak 4,96\%, beragama Katholik sebanyak 4,52\%, beragama Budha sebanyak 47,51\%, beragama Hindu sebanyak 
0,08\% dan beragama Konghucu sebanyak 0,04\%.

4. Faktor Pemuda. Pemuda kota Singkawang yang notabene sejak kecil sudah memiliki ikatan emosional antar umat beragama yang dikarenakan faktor lingkungan tempat ia tumbuh dan berkembang yang sudah di kelilingi oleh orang-orang yang berbeda agama.

Faktor penghambatnya antara lain adalah tidak cukupnya pemahaman dan pengetahuan tentang agama-agama lain secara seimbang yang akan menyebabkan kurangnya penghargaan dan munculnya sikap curiga yang berlebihan, perbedaan kebudayaan karena tingkat pendidikan yang tidak sama, juga masalah bahasa yang sangat peka dengan kelompok-kelompok tertentu. Faktor sosial politik dan beban ingatan traumatis akan konflik-konflik dalam sejarah.

\section{Simpulan}

Berdasarkan analisis terhadap data dan temuan di lapangan dapat disimpulkan bahwa bentuk kerjasama dalam toleransi umat beragama di Kota Singkawang dilaksanakan melalui wadah FKUB Kota Singkawang dan FKPELA Kota Singkawang yang merupakan satu-satunya forum komunikasi pemuda lintas agama yang ada seIndonesia. Melalui wadah ini, akan berperan memberikan nasehat, memberikan penyuluhan kepada umat beragama tentang hidup rukun dan toleran. Pengaruh ikatan emosional baik itu ikatan persaudaraan, persahabatan, keluarga dan rasa sepenanggungan dibidang sosial dan ekonomi sangat berpengaruh terhadap sikap dan perilaku umat beragama untuk saling menghargai dan menghormati antara agama yang satu dengan agama yang lainnya. Faktor lain yang juga berpengaruh adalah karena faktor lingkungan, yang notabene pemeluk agama baik itu Islam, Protestan, Katholik, Budha, Hindu, Konghucu selalu ada ditiap-tiap kecamatan. Faktor-faktor tersebut merupakan faktor utama terwujudnya toleransi antar umat beragama di kota Singkawang. Selain faktor pendukung diatas, tentunya ada beberapa hal yang menjadi faktor penghambat toleransi antar umat beragama, antara lain faktor historis yang merupakan beban ingatan terhadap konflik bersejarah, beragam kebudayaan di Kota Singkawang yang karena tingkat pendidikan dan pengetahuan tidak sama

\section{Daftar Pustaka}

Abu Bakar. "Konsep Toleransi dan Kebebasan Beragama." TOLERANSI: Media Komunikasi Umat Beragama Vol.7 Juli-Desember (2015).

Abu Bakar HM, Mualimin, dan Nurliana. "Elit Agama dan Harmonisasi Sosial Di Palangka Raya.” Khazanah : Jurnal Studi Islam dan Humaniora Vol. 16 (2) (2018).

Agus Salim. Teori dan Paradigma Penelitian Sosial. Yogyakarta: Tiara Wacana Yogya, 2001.

Arikunto, Suhardjono, dan Supardi. Penelitian Tindakan Kelas. Jakarta: Bumi Aksara, 2012.

Ghita Intan. "SETARA Institute: Singkawang, Kota Paling Toleran Se-Indonesia," 2018.

Khazanah, Vol. 17 (2), 2019 
Sri Sudono Saliro

Grim, Brian J., Roger Finke, Jaime Harris, Catherine Meyers, dan Julie VanEerden. "Measuring international socio-religious values and conflict by coding US State Department reports." JMS Proceedings, A APOR-Section on Survey Research Methods [CD-ROM]. Alexandria, VA: American Statistical Association, 2006, 4120-27.

H Noeng Muhadjir. Metode Penelitian Kualitatif: Pendekatan Positifistik, Rasionalistik, Phenomenologik, dan Realisme Metaphistik, telaah studi teks dan penelitian agama. Yogyakarta: Rake Sarasin, 1996.

Intan, Ghita. "SETARA Institute: Singkawang, Kota Paling Toleran Se-Indonesia." VOA Indonesia, 2018. https://www.voaindonesia.com/a/setara-institutesingkawang-kota-paling-toleran-se-indonesia/4690956.html.

M Atho Mudzhar. Pendekatan Studi Islam dalam Teori dan Praktek. Yogyakarta: Pustaka Pelajar, 1998.

Mun'im A Sirry. Fiqih Lintas Agama. Jakarta: Yayasan Wakaf Para Madina, 2003.

Ninis Chairunnisa. "Indeks Kota Toleran: Singkawang Tertinggi, Tanjung Balai Terendah,” 2018.

Nuryani, Titin, dan Ahmad Taufiq. "Peran Forum Kerukunan Umat Beragama dalam Memelihara Toleransi Beragama Kota Salatiga Tahun 2018.” Journal of Politic and Government Studies 8, no. 03 (2019): 381-390.

Rehayati, Rina. "Kerukunan Horizontal (Mengembangkan Potensi Positif dalam Beragama)." Toleransi 1, no. 1 (2009): 55-64.

Ridwan Lubis. Cetak Biru Peran Agama. Jakarta: Puslitbang, 2005.

SETARA Institute. "Ringkasan Eksekutif Indeks Kota Toleran Tahun 2018," 2018.

Soekanto, Soerjono. Sosiologi: suatu pengantar. Jakarta: Raja Grafindo Persada, 2007.

Sutrisno Hadi. Metodologi Research Jilid 2. Yogyakarta: Andi Offset, 2004.

Zakiyuddin Bhaidawy. Dialog Global dan Masa Depan Agama. Surakarta: Muhammadiyah University Press, 2001. 